him that this may be the case, I feel sure you will assist us by giving publicity to the matter. Of course, if this does not succeed, our association will feel bound to make a representation on the subject to the Home Secretary.

I am, Sirs, yours faithfully,

H. NELSON HARDT,

Treasurer of the United Kingdom Police Surgeons' Association. Dulwich-grove, S.E., Nov. 7 th, 1894 .

\section{EPIDEMIC SKIN DISEASE AND THE LAY PRESS.}

To the Editors of THE LANCET.

SIRS, - When I wrote to you on Oct. 13th disclaiming any connexion with an article which appeared in the Pall Mall Gazette of Oct. 11tb, containing a précis of my monograph on Epidemic Skin Disease, I stated my belief that it would hardly be necessary to trouble you to publish my letter, as it seemed to me sufficiently obvious to anyone who read it closely that I could not be held in any way responsible for that article. Subsequent events have shown me, however, that a public disavowal is desirable, and $I$ should esteem it a favour if you could find a place for this in your columns. Enclosed I beg to forward for your perusal a letter addressed to me by the assistant editor of the Pall Mall Gazette stating "that the article in the Pall Mall Gazette of Oct. 11th on the New Skin Disease was not published at your instigation or suggestion, and, so far as I know, you read it, like the rest of the world, first in our columns. The writer was never in communication with you, and was, and is still, unknown to you." The article was published entirely without my knowledge, consent, or approval.

I am, Sirs, your obedient servant,

Thomas D. Safill, M.D.

Upper Berkeley-street, W., Nov. 6th, 1894.

\section{"THE ETIOLOGY OF TYPHOID FEVER." To the feditors of THE LANCWT.}

SIRs, - I can fully corroborate Dr. Kenwood's opinion as expressed in his letter to you in your last issue with reference to the etiology of typhoid fever. I held the post of medical officer of health to the borough of Lewes for nearly twenty years, and during that period observed numerous sporadic cases in which it was utterly impossible to trace a cause from previous cases. It is true that Lewes suffered from a severe epidemic of typhoid fever just twenty years ago, since which time, in consequence of sweeping changes in sanitary matters, the disease has been conspicuous by its absence, so that an origin from that remote period might be safely eliminated. Bacteriology may be, and possibly is, doing much, yet there are among us, as Dr. Kenwood says, many who still believe cases may arise without infection from a previous case.

I am, Sirs, yours obediently,

J. G. BRADEN, M.R.C.S., \&c.,

Fellow of the Society of Medical Officers of Health. St. Margaret's-at-Cliffe, Nov. 6th, 1894

\section{"COMMON DISEASES MISTAKEN OR MISTREATED." \\ To the Editors of THE LANCET.}

SIRS,-A portion of Dr. Goodhart's interesting address published in THE LANCET of Oct. 13th refers so obviously to my writings that I hope I may be allowed a few lines to defend my position on the principle of your well-known motto of fair play. Though at first sight one might regard it as an honour that one's pages should have the attention of such a well known physician, this feeling is considerably damped down on observing that the address refers especially to mistakes and mistreatment; and still more so when it is said that someone has experimented on himself and then gone and preached a universal rule, jgnoring the very first principle of the art of medicine. If this applies to me-and it follows close on several lines which are entirely made up of the chapter headings of my book-Uric Acid as a Factor in the Causation of Disease, - I can only reply that I will undertake to produce either with diet, drags, or uric acid itself, in anyone who will lend the necessary corpus vile in a condition of good physiological activity, results which would readily be acknowledged to be identical with those
I have obtained in myself; and anyone who reads my book carefully will see that, to a considerable extent, this has already been done.

I am quite aware that drags may produce different effects in different individuals, or in different conditions of one and the same individual--e.g., chloroform; but this is generally due to very simple causes, and does not often require us to postulate the unknown quantity, individualism. Thus, salicylate of soda will produce slightly differing physio logical effects, according to the amount of uric acid it meets with. Again, the effects of opium may be determined by the presence or absence of diarrhoea or intestinal ulceration; and even a glass of water will produce different effects on the flow of arine, according to the condition of the renal arterioles when it is administered; thus, relax them by a dose of calomel or the primary action of a dose of opium, and a glass of water will cause an immediate diuresis; on the other hand contract them by the secondary action of opium, and there will hardly be any increased flow of urine. If beyond these things there is still an unknown individualism I believe that further knowledge will reduce it to the very smallest dimensions, and even now $I$ often regard the human test tube as but little less reliable than the chemist's instrument of glass. Introduce the same drug under the same conditions, and the same reaction will appear.

Dr. Goodhart says, Is it possible that all these things are produced by uric acid? I believe that it is quite possible. for though the names of these diseases are many, the effects of uric acid in producing them are few; thus local irritation of tissues acconnts for gout and rheumatism, while the effects of uric acid on the arterioles and capillaries, and so on the circulation and nutrition of the body, will satisfactorily account for all the rest. It does not of necessity follow that we should escape all these diseases if we becamo vegetarians, for the liability of young women to anæmia and of children to rheumatism is, in part at least, due to the active metabolism of childhood, which entails a large forma tion of urates; but even here diet and the introduction of urates count for a good deal (as observed by Bouchard and others), and may in many cases just suffice to make the difference between health and disease. I should be quite willing to admit that diet is a product of evolution; but surely evolution turns out both useful and harmful variationg while selection perpetnates the one and eliminates the other and it has yet to be decided whether we are to keep on with our present diet or return to that which was in use at the beginning of the century. In Persia gout is known as the disease of the rich, as in that country only the xich eat meat. In this country meat eating has gradually spread down to the lowest classes, especially in towns, and with it have come gout and its kindred dizeases: the great majority suffer in some way, and those are most fortunate whose troubles most quickly oblige thers to return to the habits of their fathers and grandfathers. Quite a large number of men in varions countries are now investigating the possibility of the causation of disease by uric acid, and when my own researches are complete, which is by no means the case yet, I shall wait these results with every confidence; and I have already mentioned the result obtained by many fellow-workers. One of these is now investigating the diet relationships of stone in India, and what he has already told me lends but littie support either to Dr. Goodhart's facts or his conclusions on the subject,

Dr. Goodhart is very certain that persistence in a rigid form of dieting does harm in some cases; I can only say that diet has cured me and made it possible for me to live and work in comparative comfort, and I could now easily give a number of similar cases from the ranks of the profession alone. I am aware, however, that in running headlong from Scylla it is possible to get too close to Charybojis, but that hardly proves that there is no via media of safety. The object which I at the present time hope to achieve by diet is rather to stop the unnecessary introduction of uxic acid into the body than to aid its elimination, though one effect of diminished introduction is increased elimination, and, con versely, increased introduction produces diminished elimination, which accounts for Dr. Goodhart's observation on the effects of more meat in children who are " uric-acid passers." If, however, as Dr. Goodhart suggests, uric acid is an effect, not a canse, it follows that uric acid is itself a harmless substance, and can be taken to any extent without effect on the circulation or nutrition. I have often taken a little uric acid, and if it is harmless there is no drug in the Pharmacopoeia toxic, for, like any drug, its $\in$ vil effects can be demonstrated 
simply by swallowing it, and if many of Dr. Goodhart's hearers are nnwise enough to try large doses we may look for some rapid promotion.

I am, Sirs, yours faithfully,

Brook-street, W., Oct. 23rd, 1894.

ALEXANDER HAIG.

\section{INOCULATION OF INFECTIOUS DISEASES.} To the Editors of THE LANCET.

SrRs, - The inoculation of any infectious disease necessarily tends to multiply that disease. As the cases increase so does the danger of infection increase. This is so alike in man and in animals. The relations between these and the laws of their evolution are as yet very imperfectly understood; but that such relations do exist has been observed from the time of Homer :

"In dogs and mules the murrain first began At length the dire infection spread to man."

The artificial inoculation of infectious diseases in animals may be a source of real danger to man.

I am, Sirs, yours faithfully,

Savile-row, Oct. 2nd, 1894. HENRY LEE.

\section{"THE POSTTION OF THE THEORY OF EVOLUTION."}

To the Editors of THE LANCET.

SIRs,-Dr. Campbell's estimate of the ethical value of evolution is true-for a certain class of mind. He is right in maintaining that a belief in determinism leads one to judge more mercifully the faults of others. But does it follow that any such rationalism is of equal value for the moral guidance of common humanity? The religious spirit "is a product of evolution, and perhaps one of the most enduring of any. It falfils its end in providing moral guidance for those to whom reason can never appeal with sufficient force. Hence every enlightened determinist and evolutionist may logically contend that a knowledge of philosophic truth is positively injurious to the mcrals of those who cannot act uprightly without a "pourboire" in the shape of reward after death. I am, Sirs, yours faitiafully,

Surbiton, Nov. 3rd, 1894. R. H. REYNOLDS.

\section{ST. JOHN AMBULANCE WORK.}

\section{To the Editors of THE IAANOET.}

SIRS, - I shall feel obliged if you will call the attention of the medical men who lecture in the above to an important point that is coming forward. Under the County Council Act there is a clause which enables classes of ambulance work to be paid for by the County Council. As a secretary of a large centre I have declined to lecture under the County Council grant on the ground that such lectures are paid out of the rates and are technical; therefore the lecturers should be paid for the lectures at the usual fee. My object in writing to you is to ask secretaries and medical men generally to abstain from lecturing under, or to classes which are receiving grants from, the County Council unless they are paid the fee of a gninea per lecture. I need not say that the old system still maintains. I think every lecturer, or medical man who has not yet lectured, will fully see the necessity of remaining firm on this point and avoiding a precedent which may involve us in very heavy work without remuneration. The London executive will, I know, support as if we are firm. I am, Sirs, yours faithfully,

$$
\text { F. J. JUDGE BALDWIN, }
$$

Nov. 5 th, 1894 Hon. Sec., S.J.A.A., Rotherham.

\section{MANCHESTER.}

(FroM OUR OWN CORRESPONDRNT.)

Prosentation to Dr. Ransome, F.R.S.

AN interesting gathering took place in the Lord Mayor's parlour of the Mancbester town hall on the 31st wlt. of medical men, of members of the Manchester and Salford Sanitary Association, and of other friends on the occasion of a presentation to Dr. Ransome, who has left for Bournemouth. Dr. Simpson presided, and in the course of his speech referred to $\mathrm{Dr}$ Ransome's many services to the cause of sanitation by his writings, by his lectures to students at the Owens College, and more especially perhaps by those given for many years past to the people in the poor parts of the town in connexion with the Sanitary Association. He had been an active and energetic member of this association since 1856 and chair man for the last fourteen years. On behalf of a few of his Manchester friends Dr. Simpson asked his acceptance of a silver inkstand, a pair of candlesticks, and an afternoon tea service. He was followed by Mr. W. Crossley, chairman of the Hospital for Consumption and Diseases of the Throat and Chest, who alluded in warm terms to his services as one of the staff of the hospital, by Dr. Leech, Dr. Sinclair, and Mr. T. C. Abbot, one of the honorary secretaries of the Manchester and Salford Sanitary Association and a member of the City Council, by which body, he said, any memorial or request from the association was received with the greatest respect and courtesy. Dr. Harris said that letters had been received from Lord Derby, Sir W. H. Bailey, and many other gentlemen who were unable to be present. In his reply, Dr. Ransome gave many interesting reminiscences of Manchester in the days of his grand. father and father, both of whom were surgeons to the Royal Irfirmary. The former was associated with the late Mr. Turner in founding the Pine-street School of Medicine, "the germ of that magnificent school which now existed at Owens College." His father was "the pupil, friend, and medical attendant of Dr. Dalton, whom he (Dr. Ransome) remem. bered." He referred also to the successful efforts he made many years ago to obtain registration of disease. This was done in Manchester by the voluntary aid of thirty or forty medical men connected with the various institutions. "To the honour of the medical profession in Manchester that retuin was continued for twenty years, and it was really the foundation of that national notification of disease which was going on now throughout the whole of England." $\mathrm{Mr}$. T. C. Horstail, in moving a vote of thanks to Dr. Simpson, expressed his gratification that he was to succeed Dr. Ransome as chairman of the Sanitary Association.

\section{Opening of the New Medical Buildings at Cwens College.}

These extensive and well-arranged buildings were opened on Oct. 30th by the Duke of Devonshire, President of the College, who was accompanied by the Dachess. Travelling by special train from Rowsby, they were met at the Central Station by Principal Ward and Dr. Leech, and arrived at the College about noon. After being received in the library by members of the governing and teaching bodies, a procession was formed to the chemistry theatre, where the Duke, attired in his robes, took bis seat as President of the College on this his first official visit. An address of welcome was presented to the Duke by the Principail, and other addresses followed. In his reply the Dake confessed that he accepted the position of President with some hesitation-even reluctance-partly because his former intimate connexion with Lancashire, partly social, partly political, had ceased and was not likely to be in the future so close and intimate as it had been in the past. But it proceeded still more from his feeling that he could lay no claim to have such scientific and literary attainments as they had a right to expect from their president. After the proceedings in the chemical theatre the Duke and Duchess were conducted to the new medical buildings. A large gathering took place in the physiology theatre of the teaching staff, of visitors, and a numerous demonstrative body of students. Here other addresses were presented to the Duke, and at the close of his reply he declared the new buildings open, and expressed his wish for their prosperous and successful career. At two o'clock a luncheon took place in the College, at which about eighty sat down. After the luncheon the Duke, in response to his health, gare an interesting account of the great changes that, within bis own recollection, had taken place in Lancashire as to mode of life the thirst for knowledge, and the opportunities for its acquisition. When the luncheon was concluded, there was another adjournment to the new buildings, where a reception (to which about 3500 invitations were sent out) was held. From the crowded condition of the staircase and corridors it seemed as if all those invited were present. The Duke and Duchess of Devonsbire and Principal Ward went through their fatiguing duties with exemplary patience and great power of endurance, and it must have been a relief when the ceremony came to an end. 